China Perspectives

2020-1 | 2020

Sights and Sounds of the Cold War in Socialist China and Beyond

CinemaScope's Chinese Journey: The Technological Modernisation and the Logistics of Perception of the Cold War

Ling Kang

(2) OpenEdition

Journals

Electronic version

URL: https://journals.openedition.org/chinaperspectives/9823

DOI: 10.4000/chinaperspectives.9823

ISSN: 1996-4617

Publisher

Centre d'étude français sur la Chine contemporaine

Printed version

Date of publication: 1 March 2020

Number of pages: $7-13$

ISSN: 2070-3449

Electronic reference

Ling Kang, "CinemaScope's Chinese Journey: The Technological Modernisation and the Logistics of Perception of the Cold War", China Perspectives [Online], 2020-1 | 2020, Online since 01 March 2021, connection on 02 July 2021. URL: http://journals.openedition.org/chinaperspectives/9823 ; DOI: https://doi.org/10.4000/chinaperspectives.9823 


\section{CinemaScope's Chinese Journey: The Technological Modernisation and the Logistics of Perception of the Cold War}

ABSTRACT: This article argues that the advent of the technological system of CinemaScope in socialist China should be understood as a historical product of the specific material, cultural, and political conditions and configuration of the Cold War. On the one hand, it is the cultural network of the communist bloc that enabled China to obtain this new technology of media infrastructure. On the other hand, the social discourse of CinemaScope embodies the Manichaean Cold War narrative that worked to justify the political-ideological supremacy of communism by articulating a technological modernisation superior to the capitalist model. What is more, CinemaScope also bespeaks the logistics of perception that effectively turns people's perceptual experience into a political battlefield of the Cold War.

KEYWORDS: CinemaScope, socialist China, Cold War, cinematic technology, the logistics of perception, Sino-Soviet relations, technological modernisation.

\section{Introduction: CinemaScope on the night of the Party's anniversary}

( $\mathrm{n}$ the night of 1 July 1957, the thirty-sixth anniversary of the establishment of the Chinese Communist Party (CCP), the Prime Minister Zhou Enlai 周恩來 went to see a movie. This was apparently not a leisure activity. Along with him were Deputy Prime Minister Chen Yi 陳毅, Minister of Culture Mao Dun 茅盾, the representative of the Soviet Embassy in China, P. A. Abrasimov, and almost all the top leaders in the cultural sector of the Chinese government, not to mention film directors, playwrights, actors and actresses, engineers and technicians from both China and the Soviet Union. Together, they were there to celebrate the inauguration of China's first CinemaScope (kuanyinmu litisheng 寬銀幕立 體聲, literally "widescreen stereophonic") movie theatre, the Capital Theatre (Shoudu dianyingyuan 首都電影院).

The debut of CinemaScope in China was a long-anticipated event. During the early People's Republic of China (PRC) period, the technology of widescreen cinema attracted a huge amount of state investment, social resources, and public interest. Although its implementation required a thorough reformation of the process of film (re)production (the reconstruction of film studios and movie theatres, the updating of mechanical devices, the procedures and techniques of film-making, the institutional realignment and redistribution of personnel and resources, etc.), it did not prevent Chinese filmmakers from fully embracing this new technological system. While more detailed discussions of the phenomenon and its significance will be provided in the following sections, it suffices to say here that Zhou's visit on the night of the Party's anniversary marked the culmination of concurrent attention to CinemaScope among the state and the public. Not surprisingly, the new theatre enjoyed instantaneous success. All the tickets were sold out in just one hour. The theatre was booked until the end of September within one day after registration started. To meet the demand, it had to keep increasing the number of screenings per day, with the first session starting as early as 6:30 in the morning (Chen 1957: 27-9). ${ }^{2}$ Soon after that, more theatres in Shanghai, Guangzhou, Tianjin, and Nanjing started renovating to install the new system, along with the inception of production plans for several widescreen films.

What significance did this particular cinematic format have for communist China in its early years that merited so much cultural, economic, and political investment? Media reports at the time never for a second forgot to attribute the format's appeal to its technological parameters its screen (curved!) was 2.5 times larger than the old one, its stereophonic system comprised eighteen speakers as opposed to the original mono system, etc. Following the orbit, official and scholarly accounts adopted a similar technological determinism by interpreting the system as a significant

1. “我國第一座寬銀幕立體聲電影院開幕” (Woguo diyizuo kuanyinmu litisheng dianyingyuan kaimu, The inauguration of the first CinemaScope movie theatre of our country), Xinhua News Agency, 1 July 1957.

2. The film screened that night was a Soviet work, Prologue of Revolution (Geming de qianzou 革命 的前奏). Throughout its run, it had 1,062 screenings with a total audience of 960,000 (Chen 2005: 444). 
step in the teleological process of technological progress that would better serve the interests of the film audience (Qiao 2005; Xu 2005). However, as Jonathan Sterne (2003: 2) reminds us, the development of media technology cannot be fully understood by "considering simple mechanical possibility." Rather, it always "crystallized and combined larger cultural currents." This is especially true for CinemaScope. For this large-scale, state-sanctioned endeavour, an adequate understanding of it must grasp the fetishization of its technological characteristics as the crystallisation of the complex nexus of material, cultural, and political conditions at this specific historical juncture.

This article takes up the task. However, it does not attempt to offer a comprehensive history of CinemaScope. Rather, I argue that the advent of CinemaScope in China should be understood as the historical product of the country's involvement in the cultural Cold War between the communist and the capitalist camps. Coined by Frances Stonor Saunders (2001), the notion of cultural Cold War points to the field of conflict and contestation beyond the realm of military deployment and political antagonism in which the Cold War rivals competed for ideological supremacy through cultural mediums such as film, radio, literature, and mass media. While the literature on the writers, artists, institutions, and policies of the two superpowers, the USSR and the US, is now voluminous, more accounts on how the cultural Cold War took shape in China are still needed. Xiaojue Wang has demonstrated that the Cold War discourse was deeply ingrained in the competing visions of Chinese modernity across the Bamboo Curtain. She examines how different writers in mainland China, Hong Kong, and Taiwan contested and overcame the dichotomous Cold War discourse and its "Manichaean myth of clash between the forces of good and evil, capitalism and communism, democracy and authoritarianism" (Wang 2013: 4). For Nicolai Volland, the story of the Cold War in China is not just one between the two camps, but also within the communist bloc itself. He reveals the dynamic cultural network among communist countries in which the fervent interactions among writers, circulation of texts, and translation of literary themes and subjects constituted their own cultural universe. The cultural Cold War is thus not just "Manichaean," it is "singular and dualistic at the same time" (Volland 2017:6).

The history of CinemaScope betrays a similar "singular and dualistic" nature. To elaborate, this article will consist of three sections. Firstly, tracking the knowledge transfer of CinemaScope from the Soviet Union to China, I argue that the communist bloc constituted a transnational network of film production that made it possible for China to obtain this new media technology. In other words, the Cold War division not only draws an ideological boundary, but also demarcates the global transfer of technological knowledge of media infrastructure. Rather than being passively influenced by the Soviet Union, China actively participated in and utilised the network to catch up with cutting-edge technological innovations.

Secondly, like many other technologies, the development of CinemaScope was rooted in the Cold War cultural competition that linked art to power and turned the achievement of cinematic technology into the indicator of political supremacy. Focusing on the social discourse of CinemaScope in this section, I point out how the mass media situated CinemaScope in the distinct technophilic framework and encoded in it the social imagination of the state project of technological modernisation. It spectacularised the ideology of the communist state by forging the social spectacle of its technological achievements. The narrative of CinemaScope became a discursive space in which filmmakers and technicians envisioned and articulated a communist technological modernisation both alternative and superior to the capitalist one.
Thirdly, enthusiasm for the technology of widescreen cinema during the Cold War was also fuelled by what Paul Virilio (1989) terms "the logistics of military perception." Examining the use of cinema in war and military propaganda, Virilio contends that cinema becomes a weapon of perception due to its ability to create "magical spectacle" that could be used to manipulate the perceptual identification and differentiation of its audience. Appropriating his notion, I argue that the unprecedented sensory power of widescreen cinema made it the perfect tool through which the state could (re)define its sensory relationship with its people to construct political identification. The development of CinemaScope thus highlights the process by which the Cold War turned the realm of human perception into a new political battlefield. Underlying the ideological confrontation is a shared desire on both sides for a more effective form of technological domination. And it was precisely the intensifying Cold War conflict that propelled the global expansion of the logistics of perception across the Iron Curtain.

Methodologically, this study combines the approaches of film studies and cultural history. Whereas the former allows me to offer an account of technological development as well as an analysis of the cinematic text, the latter helps me situate them in the Cold War historical context to see how their meaning and relevance, rather than being self-evident, were generated by the specific social and political discourse. I will base my study on prestigious film magazines of the socialist period such as Popular Cinema (Dazhong Dianying 大衆電影) and Chinese Cinema (Zhongguo Dianying 中國電影) to showcase the mainstream understanding of CinemaScope, but will also pay specific attention to the long-overlooked vision of cinematic technicians by drawing from the leading technological journal Cinema Technology (Dianying Jishu 電影技術) as well as translations of technological materials. By bringing together both the ideological and the technological perspectives, I show how the implementation and discourse of CinemaScope provide a lens through which we can better understand the discursive and affective frameworks in which the significance of cinematic technology was configured and articulated vis-à-vis the cultural Cold War.

\section{Cinematic technology in the Cold War cultural network}

In the fall of 1956, a team of three Chinese filmmakers - including the director Shen Fu 沈浮, the cameraman Luo Congzhou 羅從周, and the recordist Miao Zhenyu 苗振宇 - set out on a trip to the Soviet Union. Their mission was simple: to learn and bring back the skills and knowledge of CinemaScope. Upon their arrival, they were warmly welcomed by their Soviet colleagues and soon arranged to work as interns in the respective departments of the famous Mosfilm. In the months that followed, they not only took courses on the equipment and procedures of CinemaScope filmmaking, but also participated in actual film production. The knowledge and experience they gained there laid the essential foundation for the development of widescreen cinema in China (Shen 1957; Miao 1957).

This was not the first time Chinese film workers went to the Soviet Union to learn cinematic technology. Since 1954, multiple teams had gone to investigate and learn about the development of the Soviet film industry. Such activities were not limited to China and the Soviet Union. Underlying them was the vast network of film exchanges among communist countries in the 1950s and 1960s. Immediately after the establishment of the PRC, film experts from the Soviet Union, Czechoslovakia, and East Germany had already been deeply engaged in the post-war restoration of the film 
industry in communist China. They directed and cooperated with their Chinese colleagues in film productions, reconstructed and standardised the management systems and technical procedures of film studios, trained and taught Chinese technicians and students in film academies, and built new movie theatres and manufactories for mechanical cinematic devices. Furthermore, China itself was an important hub in the communist cultural network. It not only hosted foreign filmmakers from Vietnam, North Korea, Romania, Cuba, and Albania, but also sent its own film experts and exported its cinematic devices to those countries (Xu 2005). With limited film imports from the Western world, as well as technological blockades, the communist bloc constituted its own film universe.

The transference of knowledge of CinemaScope from the Soviet Union to China marked only a new episode in this vigorous network. More importantly, it points to the technological dimension of film exchange, which has not gained enough scholarly attention (Chen 2009). While previous studies on the Sino-Soviet cinematic relationship concentrate mostly on the artistic and ideological aspects, especially how the Soviet models of aesthetic doctrine, character setting, subject and theme, and filming techniques influenced Chinese films, the dissemination of CinemaScope and other cinematic technologies in the communist film network suggests that the Cold War division drew not only ideological boundaries but also material ones demarcating the global circulation of technical knowledge of media infrastructure. Through the operation of the network, the films of the communist bloc not only shared common aesthetics (especially socialist realism) and similar techniques of montage and mise-en-scène, but on a more fundamental level were also made with similar mechanical devices and technological parameters: cameras, microphones, the acoustic settings of film studios and theatres, techniques of costuming and lighting, projectors, loudspeakers, screens, etc. In other words, the Cold War network helped normalise the media infrastructure of communist cinema. Consequently, the affinity of communist films lies not only in their diegetic worlds and ideological messages, but also in the extra-diegetic, material disposition of their audience's cinematic experience: the quality of cinematic sound, the size and brightness of the screen, the spatial structure of the movie theatre, and other sensory perceptions of cinema.

The construction of infrastructure points to something beyond its technical functioning. In his theorisation of infrastructure, Brian Larkin (2013: 329) argues that infrastructures "emerge out of and store within them forms of desire and fantasy and can take on fetish-like aspects." Likewise, for Chinese filmmakers and audiences alike, CinemaScope should be viewed as a vehicle whereby the desire for "the possibility of being modern, of having a future" is transmitted and materialised (Larkin 2013: 333). In Shen Fu's report of the internship, besides a comprehensive introduction to the development of CinemaScope in the Soviet Union, he asserted, "The road of world cinema in the future is definitely the road of widescreen cinema" (Shen 1957: 93). When carried out properly, CinemaScope would provide brand new possibilities and vocabularies to reconfigure the visual and auditory representation of socialist history and reality on screen. In other words, CinemaScope was more than a specific technological system. It registered the imagination of the future form of cinema.

At that time, the Soviet Union undeniably set the standard for such a future. As Volland (2017: 108) points out, the Chinese mass media often portrayed the Soviet Union as the most advanced nation on earth. With regards to cinema, the Soviet Union had also "made huge accomplishments in the development of CinemaScope on the world scale" (Shen 1957: 92). Therefore, rather than a new genre of film, CinemaScope was conceived more as a new norm of film. China's quest for CinemaScope marked the desire not just to obtain the most advanced technological innovation, but also to proclaim its leadership in the global cultural and technological competition now and in the future.

Determined to catch up with its big brother, China mobilised the communist cultural network by all available means. In spite of the newborn country's limited foreign currency reserves, it managed to purchase a large number of foreign filming, recording, and projection devices from the Soviet Union and East Germany (Xu 2005: 37-88). The major film journals not only introduced the features of CinemaScope in detail, but also covered the developments of this system in other communist countries as marking significant achievements in both artistic, technological, and even political terms (Feng 1955: 95-6; Su 1957: 17-9). As preparation for the system's implementation, film technicians translated numerous academic articles and technical manuals for CinemaScope into Chinese, including two foundational works: an anthology by the chief engineer of the Beijing Film Studio, Luo Jingyu's 羅靜予, Selected Translations on CinemaScope (Kuanyinmu litisheng yiwen xuanji 寬銀幕立體聲電影譯文選集), and Wang Ping's 王平 translation of Vysotsky's comprehensive monograph CinemaScope Films (Kuanyinmu litisheng dianying 寬銀幕立體聲電影). Chinese CinemaScope films were sent to the Soviet Union for postproduction work, while Soviet experts were invited to China to teach CinemaScope technology and cooperated on the future production of widescreen films (Xu 2005: 83-4). Shen, Luo, and Miao's trip to the Soviet was part and parcel of such a grand national trend.

After they came back, they immediately cooperated on the production of the first Chinese CinemaScope feature film, New Story of the Old Soldier (Laobing xinzhuan 老兵新傳). Released in 1959 as a film celebrating the tenth anniversary of the founding of the People's Republic of China, the film functioned as a "model play" that exemplified the new technological model of filmmaking. It was selected to represent China in the First Moscow International Film Festival in 1959 and won the Silver Medal for Technological Achievement. As the chief engineer of the Shanghai Film Studio, Lin Shengqing 林聖清, and his colleague Xue Zhichang 薛志 昌 (1959) remarked, the success of this film showed that after studying CinemaScope in the Soviet Union, China had caught up with this new stage in the development of cinema. With such recognition, Chinese filmmakers could assert their forefront position in the race for cinematic technology and for technological modernisation.

\section{The supremacy of communist technological modernisation}

But what kind of technological modernisation is it? Whereas the previous section shows how the communist cultural network enabled China to obtain the most cutting-edge cinematic technology that encoded the desire "of being modern, of having a future" (Larkin 2013: 333), this section will demonstrate the "Manichaean" nature of this imagination of technological modernisation. I argue that the social discourse of cinematic technology in communist China is informed by the compelling need to overpower the absent presence of its Cold War rivalry. The filmmakers, technicians, and critics alike turn their narrative of cinematic technology into a discursive space in which they can articulate their conception of communist technological modernisation (and the underlying communist ideology) that are both alternative and superior to the capitalist ones.

The discourse of cinematic technology in communist China was characterised by growing technophilia among mass media. Film magazines 
such as Popular Cinema frequently featured introductory works detailing the operation of film studios as well as the concepts, methods, devices, and principles of optical recording, magnetic recording, sync sound, dubbing, Foley techniques, and so on. In these works, cinematic technology itself became a central subject whose significance was articulated external to the diegetic world of any single film. In her discussion of Republican cinematic discourse, Zhang Zhen (2005: 136-7) suggests that inscribing film within a technophilic framework is "no doubt in tune with the May Fourth exaltation of enlightenment and modern science." The discussion of cinematic technology in communist China is also associated with the promotion of science and technology. What is conspicuous here is the role of the state in such promotions. With its massive investment in the construction of cinematic infrastructure (film studios, movie theatres, journals, academies, research labs, factories, foreign purchases, etc.), communist China maintained deep involvement in the business of cinematic technology. The media coverage of cinematic technology was thus often inscribed in the state's project of achieving the dream of technological modernisation. The recurrent stories and images of the communist state's grand projects effectively tied the development of film technology to the political ideal of national construction. More important, as Larkin points out, to the extent that technology represents "the power of science to rationally order and control the natural world," the state's mastery of technology becomes "part of the conceptual promise" of its rule and self-justification (Larkin 2008: 7). In this sense, the visibility of technology bespeaks the visibility of the state's power to control and manage the objective world in which its citizens dwell.

However, I argue that the assertion of the role of the state not only aims to justify its domestic authority and rulership, but also has an important Cold War connotation. The media obsession with 國產 (guochan, domesticallymade) cinematic mechanical devices is a telling example here. Every guochan device, from camera to projector to microphone to recorder and so forth, was markedly celebrated in mass media as displaying the independent and magnificent potential of the Chinese people in technological invention. The first guochan magnetic sync recording system, for example, not only received voluminous media coverage, but was even branded by the Shanghai Film Technology Factory as "Leap Forward" (Yuejin pai 躍進牌) to fashion its identity as the achievement of the Great Leap Forward movement (Xue 1959: 7-10). As the slogan of the movement, "To surpass the UK and US," clearly indicates, the movement was deeply embedded in the desire of China to compete with and overpower the capitalist world. ${ }^{3}$ Branding the recording system "Leap Forward" thus turned the invention of cinematic technology into the political manifestation of China's determination to "surpass the UK and US."

In other words, the conception of the significance of CinemaScope is deeply grounded in the Cold War Manichaean discourse. Caute observes that in the Cold War USSR, the state launched an "inventions campaign" during which the Soviet Union claimed to have made almost all modern technological inventions - telegraph, airplane, steam locomotive, bicycle, radar, television, synthetic rubber, penicillin, etc. - independently of or prior to the West. By making these claims, the Soviet Union attempted not only to "immunise itself against Western achievements," but also to "vindicate their self-respect and destroy the (...) old sense of inferiority" (Caute 2003: 36-7). The obsession with guochan devices in China arguably showcases a similar Cold War mentality that views technological inventions as a means of competing for political and ideological superiority. The media reports of guochan devices not only publicised the state's infrastructural projects, but also manifested a crucial performative dimension aimed at spectacularising the ideology of the communist state by forging the social spectacle of its technological achievements.

Comparing the technological specifications of the Soviet Union's widescreen system to America's, the deputy director of the Chinese Cinematic Science and Technology Research Centre, Ma Shouqing 馬 守清 (1959: 20-1), concluded that the Soviet one was evidently better. Widescreen cinema, like the "space station the Soviets just launched," (ibid.: 20) represented a most glorious achievement exemplifying "the grandeurs of communist construction by the Soviet people under the Party's leadership" (ibid.: 20). The deputy director of the Chinese National Film Bureau, Situ Huimin 司徒慧敏 (1955: 22-3), also praised the brilliant achievements of cinematic science and technology in the Soviet Union, which "left the capitalist world far behind" (ibid.: 22). The Soviets "spent only ten years or so in catching up with what the capitalist world has accomplished in several decades" (ibid.: 22). Associating CinemaScope with the space race - the "quintessence of scientific and industrial competition" between the USSR and the US (Caute 2003: 38) - these authoritative voices firmly situate cinematic technology in the Cold War context.

More importantly, the superiority of communist CinemaScope was manifested not only on the level of technological specifications, but also on the deeper level of the developmental logic of cinematic technology and its underlying social-political system. For example, Luo Jingyu (1957: 20-2) argued that what the rapid progress of cinematic technology in the Soviet fundamentally bespoke was that "when people get rid of the exploitative social system, the social productivity would necessarily start to increase in an unprecedented manner, and the development of science and technology would necessarily advance to the leading position in the world" (ibid.: 20). The "exploitative social system" here obviously refers to the capitalist system. For Chinese filmmakers, the capitalist film industry as exemplified by Hollywood constituted the evil other to the technological modernisation they proclaimed. The chief editor of Popular Cinema, Jia Ji 賈雲 (1957), asserted that the difference between capitalist cinema and communist cinema lay in that whereas the former capitalised on commercial film, market competition, and corporate investment, the latter conceived its only interest as serving the people (renmin 人民), thus representing a different, and certainly superior logic in cinematic development. In a similar vein, the director of the Central Film Management Bureau, Chen Huangmei 陳荒煤 (1957), also cautioned that the pursuit of commercial profit would seriously undermine the central mission of socialist cinema to serve and educate the people through its artistic and social values.

In the discursive framework as such, the history of widescreen cinema is fashioned as a perfect case by Chinese filmmakers and critics to articulate communism's superiority over Hollywood's profit-driven technological modernisation. To demonstrate the capitalist system's intrinsic and institutional defects that would necessarily repress the potential of the film industry to serve the people, Guan Li 管虫 (1957:63-4) recounted the history of widescreen cinema in the West since Abel Gance's invention of his multi-camera device in the late 1920s. He argued that Gance's invention failed, not because of its technical flaws, but because the capitalists in the film industry back then were "busily calculating their box office incomes" (ibid.: 63). They refused this new format for being "too artistic" and lacking commercial potential. It was not until the early 1950s - when the film industry was facing the economic crisis brought by the rise of television -

3. For a discussion of the relationship between the Great Leap Forward movement and modernisation, see Rana Mitter (2013: 134-7). 
that businessmen suddenly recalled and appealed for widescreen technology. For Guan, such a twist explicitly manifested that "what dominates cinema in the capitalist world has always been the box office and commercial profitability. They could hardly be reconciled with the pursuit of artistic values" (ibid.: 63). Gance's tragedy was thus "inevitable," for he was only concerned about "the enormous expressive capacity of the art of widescreen cinema while being ignorant of investors' calculations" (ibid: 63). Unfortunately, it was the latter that constituted the sole legitimate motivation for technological development in the capitalist system.

In comparison, the development of widescreen cinema in the communist world assumed a different driving force. Communist countries invested in the new format not because it would be profitable, but because the technology would "enrich the audience's visual impression of the beautiful external world," (ibid.: 64) hence "drastically enhancing the sense of reality and the emotional affect" (ibid.: 64) of the spectator. In other words, whereas the capitalist film industry was manipulated by businessmen and their commercial interests, communist countries wanted to make progress in widescreen technology for its promising artistic potential.

It is not hard to find historical facts that run counter to Guan's narrative. For example, the 1950s CinemaScope was by no means a simple resurrection of Cance's technology. To use John Belton's (1988: 28) words, "the CinemaScope of 1953 bears only a superficial resemblance to the anamorphic technology introduced in the 1920s" (ibid.). CinemaScope should be understood as a "multitechnological package" of which many components are "made possible only by postwar technological development" (ibid.). What is more, market competition with television was also not the sole rationale for investment in the widescreen technology. Other important factors included the post-war transformation of leisure activities, the redistribution of population, changes in middle-class culture, and so on (Belton 1992).

However, it is precisely the biased and selective nature of Guan's narrative that attests to its Cold War origin. The difference in the realm of cinema gradually translates into the comparison between the two political systems, and ultimately into the self-justification of communist ideology. Using CinemaScope as a case in point, Chinese filmmakers and technicians envisioned communist technological modernisation that was better than the capitalist one in terms of both its technological achievements and developmental logic. Labelling commercial profitability as the hallmark of the capitalist system, they argued for a desirable developmental trajectory of cinematic technology (and film industry in general) that would do away with, or at least not be solely dominated by, capital flow and market concerns. In the communist world, the development of the film industry should ultimately be of value to the cultural life of the majority of the people. And the mission of cinematic technology was to "serve the people" rather than the capitalists (Lin and Xue 1959) - though what constituted the interests of the people remained open to the contestation of different forces in which the state definitely occupied the dominant role.

\section{Widescreen cinema and the logistics of perception}

In the previous two sections, I have discussed how the Cold War cultural network among the communist countries enabled the circulation of cinematic technology, and how the Chinese filmmakers used the discourse of CinemaScope technology to articulate the supremacy of communist technological modernisation. However, the historical connection between CinemaScope and the Cold War has yet another layer to be investigated: its instrumental role in propaganda campaigns.

Compared to other items in the cultural Olympics of the Cold War, CinemaScope stands out for its unprecedented sensory impact on human perception, which could be used to manipulate the ideological and political identification of the spectator. One of the earliest theorists of CinemaScope, André Bazin (2014: 271), already saw in CinemaScope a potential to revert to "film's unique superiority" over other media forms: "its potential to deliver spectacle." Similarly, Charles Barr (1963: 9-11) praised CinemaScope for its "physical sensation," "vivid sense of space," "greater physical involvement," and "sensation of movement."

However, as Ariel Rogers (2013: 32-5) aptly points out, the huge sensory power could also function to "govern the human perceptual apparatus." Immersing the spectator in the widescreen visual experience and stereo sound, the bodily experience of CinemaScope would likely "elicit psychosomatic responses" and hence "subject the viewer to the 'will' of the film" and "render audiences susceptible to control from above."

Such a danger - or rather, potential - naturally found its place in the Cold War, in which both sides recognised this capacity as useful to their propaganda apparatus. John Belton (1992: 88-90) finds that during the Cold War, widescreen technology was often used "as exhibits in national pavilions at world's fairs." Whereas the United States "defeated the rival exhibit of the Soviet Union" in the 1955 Bangkok World Trade Fair, three years later, the Soviet Union fought back and won the Grand Prize at the Brussels World's Fair with its widescreen film Great Is My Country. Anti-communist intellectuals in the US also warned against "the introduction of stereophonic sound and Cinemascope-type screen" in the Soviet Union, worrying that it would add "some very strong features in their favor" to Soviet films "designed for foreign festivals and for gaining prestige abroad" (Caute 2003: 159).

In the Cold War international propaganda contest, widescreen cinema became "a site for polemical confrontation" and "an index of technological prowess" (Belton 1992: 90). Caute (2003: 4) points out that the Cold War rival systems actually shared a remarkable consensus on a variety of issues, including faith in technological modernisation and its power to manage and harness the natural world to human needs. With respect to CinemaScope, it could be added that the two parties also agreed on the power of technology to manage and control human beings themselves. The competition over this power served as a significant driving force for the development of widescreen technology.

In this sense, I argue that the enthusiasm for CinemaScope during the Cold War could be understood in terms of Paul Virilio's conception of "the logistics of military perception." In his study of the use of cinematic technology in war, the French philosopher contends that cinema became a significant weapon of perception that could serve the war with its ability to produce "magical spectacle." The spiritual power of the spectacle would "captivate" the enemy to manipulate their sense of fear and hope. To the extent that the film-as-weapon could "make themselves felt through chemical, neurological processes in the sense organs and the central nervous system," it was able to affect "human reactions and even the perceptual identification and differentiation of objects" (Virilio 1989: 7-8). It is on this perceptual level of war that Virilio claims that "once the cinema was able to create surprise (technological, psychological, etc.), it effectively came under the category of weapons" (ibid.: 10). Abel Gance, who is depicted as the poor, artistic-minded inventor of the widescreen device in the 1920s by Guan Li's aforementioned narrative of the history of widescreen technology in the West, actually worked for the army during WWI. He not only employed real soldiers in his films, but his conception of cinema was also close to that of 
the "war machine." Virilio argues that Gance's invention failed because its cinematic power did not catch up with the dynamism of the military: it was "incapable of inventing its own atomic bomb" (ibid:: 34 ).

The notion of the logistics of perception sheds new light on the development of CinemaScope in the Cold War. With its greater ability for spectacle-creating, CinemaScope arguably served as a better weapon in this new military and political battlefield: the realm of human perception. However, whereas in "hot" wars, the perceptual weapon of cinema was mainly used to bombard "the sense organs and the central nervous system" (ibid:: 8) of the enemy, the Cold War was characterised by the physical absence of the enemy (with the possible exception of occasions such as international exhibition fairs). Therefore, in the Cold War, the major target of the cinematic weapon expanded to the domestic audience, while its objective became the construction of perceptual identification with the political power of the state, be it capitalist or communist.

Chinese CinemaScope films should be read as perceptual weapons of the Cold War as well. In a 1956 interview, the chair of the department of cinematography of the Beijing Film Academy, Zhu Jinming 朱今明, anticipated that future domestic CinemaScope films would exhibit the "infinite beauty of our country's natural landscape" and the "grandeur of masses of people gathering in front of Tiananmen Square." Both scenes bear explicit ideological messages of nationalism and the mass politics of the state (Reporter 1956: 30-1). In effect, the early production of CinemaScope films did follow this principle. For example, the first Chinese CinemaScope feature film, New Story of the Old Soldier, extensively featured images of natural landscape and the collective masses that had clear political connotations. The film tells the story of how former military cadre Lao Zhan 老戰 volunteered to reclaim the Great Northern Wasteland (Beidahuang 北大荒, GNW hereafter) in Heilongjiang Province. With the help of workers, peasants, and students of agricultural mechanics, Lao Zhan and his colleagues finally overcame the harsh natural environment and built the first state farm.

The project of mass reclamation of the GNW was in no sense new to the audience. Disseminated throughout the state propaganda machine since 1948, stories of the project not only eulogised people's efforts in achieving a difficult agricultural project, but also made the wildness of the GNW's natural environment nationally renowned. Film scholars have long noticed how the widescreen representation of large-scale natural landscape can have a propagandist function. John Belton (1992: 89-90) notes that early widescreen films in the United States belonged predominantly to the genre of travelogue that often "fetishized the American landscape" by "barnstorming through Bryce Canyon, Yosemite, the Grand Canyon, and Zion Canyon in Zion National Park." Displaying "the scenic wonders of America to both domestic and foreign audiences," these scenes carried an overt ideological undertone of American patriotism and thus anticipated the potential value of the format as "an instrument of American propaganda."

The representation of the GNW in New Story certainly implicates the possibility for the spectators to entertain their fascination with one of the country's most famous "scenic wonders" in the theatre. More than that, it takes the ideological function one step further by also displaying the spectacle of the people in conquering such scenic wonders. For example, in the climax of the film, the camera provides a panoramic view of the collective labour of the masses. With people and machines spread out in an orderly manner across the vast farmland, the scene not only implies that the harsh environment has now been tamed and transformed into an object of exploitation by the masses, but also turns the masses themselves into a spectacular visual object confronting the spectator. The massive spreadout complex of the collective covers simultaneously the farmland and the audience's vision, constituting the conquering of nature and of the spectator at the same time.

It is in scenes like this that CinemaScope attains its full potential as a perceptual-ideological weapon. Whereas the diegesis depicts how the people of the new-born communist state put the chaotic and turbulent environment into order, allegorically, the natural environment could well be read as the international political arena of the Cold War, the antagonism of which was no less hostile. Virilio (1989: 51) argues that cinemas "were training camps which bonded people together in the face of death agony, teaching them to master the fear of what they did not know." In the training camps of CinemaScope, then, images like that certainly functioned as logistical supplies for the communist audience. They spectacularised the communist ideology of collectivism by turning it into the sensationally overwhelming visual representation of the collective. The perceptual impact of the images attributed to communism and the communist state an illusory power that would purportedly defy any difficulties, and hence better prepare the audience to master their fear in the Cold War waged in the fields of both politics and perception.

\section{Concluding remarks}

Statistics show that in the late 1950s, the annual production of CinemaScope films in China accounted for nearly $10 \%$ of the total number. While we do not have a reliable source of actual audience figures for these widescreen films, what we do know is that the number of widescreen theatres increased rapidly from nine in 1958 to 17 in 1959 to 50 in 1960 (CFDEC 1961), while the number of regular theatres increased about 20\% every year (Chen 2005). However, what is equally if not more important than these figures are the social discourses constructed around this technological system among technicians, filmmakers, and in mass media. What they show, as this article proposes, is that rather than simply a "better" cinematic technology in a teleological process of technological improvement, it is more productive to understand CinemaScope as a historical product of the specific material, cultural, and political conditions and configuration of the Cold War. On the one hand, it was the cultural network of the communist bloc that enabled China to obtain this new technology of media infrastructure. On the other hand, the social discourse of CinemaScope embodied the Manichaean Cold War narrative that worked to justify the political-ideological supremacy of communism by articulating a technological modernisation superior to the capitalist model.

The examination of CinemaScope in turn sheds new light on the conception of Cold War. The technology highlights the significant role of the logistics of perception on both sides of the rivalry. The binary ideological narrative of the Cold War disguised the shared desire to manipulate people's perceptual identification through technological means. The necessity of the logistics of military perception constitutes the affective framework in which the technological infrastructure of CinemaScope and its affective affordance became meaningful.

This explains why, whereas the discourse of CinemaScope is characterised by the distinct binary relationship between the communist bloc and the capitalist bloc (and the supremacy of one over the other), the technology of CinemaScope seems to betray a sense of universality. Although the Soviet Union was unquestionably the major source of technological knowledge of CinemaScope, Chinese technicians did not turn away devices and references 
from Western countries. For example, the magnetic film coating machine used in the production of New Story was a French product. Luo Jingyu's 1957 anthology Selected Translation on CinemaScope, which served as a technological guidebook, included articles from the Soviet Union, the United States, Britain, France, and the Netherlands. The footnotes of articles in technical journals such as Cinema Technology also cited a substantial number of publications from the United States.

The universality of the technical parameters of CinemaScope falls outside the demarcation of the Cold War binary. It points to the unified Cold War modernity of media technology that I classify as the concept of the logistics of perception. At the core of the concept is the desire to use the perceptual power of media as a tool of ideological manipulation. In this sense, what
CinemaScope's Chinese journey ultimately suggests is that, apart from the social, political, and ideological aspects, the Cold War was also a war of perception. And it was precisely the intensifying Cold War competition that served as the driving force for the global expansion of the logistics of perception - in which China was just a new (and certainly not the final) stop.

I Ling Kang teaches modern and contemporary Chinese literature at Fudan University, Shanghai, P.R.C.. He received his PhD in Chinese and Comparative Literature from Washington University in St. Louis (lingkang@wustl.edu).

Manuscript received on 23 March 2019. Accepted on 14 October 2019.

\section{References}

BARR, Charles. 1963. "CinemaScope: Before and After." Film Quarterly 16(4): 4-24.

BAZIN, André. 2014. André Bazin's New Media. Dudley Andrew (ed. \& trans.). Oakland: University of California Press.

BELTON, John. 1988. "CinemaScope and Historical Methodology." Cinema Journal 28(1): 22-44.

BELTON, John. 1992. Widescreen Cinema. Cambridge, MA: Harvard University Press.

CAUTE, David. 2003. The Dancer Defects: The Struggle for Cultural Supremacy during the Cold War. New York: Oxford University Press.

CFDEC (China Film Distribution and Exhibition Corporation) 中國電影 發行放映公司. 1961. 中國電影發行放映統計資料彙編 (Zhongguo dianying faxing fangying tongji ziliao huibian, Statistics on the Distribution and Exhibition of Films in China). Beijing: CFDEC.

CHEN, Bo 陳播 (ed.). 2005. 中國電影編年紀事發行放映卷 (Zhongguo dianying biannian jishi: faxing fangying juan, Chronicle of Chinese Cinema: The Volume of Distribution and Exhibition). Beijing: Zhongyang wenxian chubanshe.

CHEN, Che 陳澈. 1957. “我國第一座寬銀幕立體聲電影院誕生了” (Woguo diyizuo kuanyinmu litisheng dianyingyuan dansheng le, The first CinemaScope movie theatre of our country was born). Dazhong Dianying 大衆電影 $14: 27-9$.

CHEN, Huangmei 陳荒煤. 1957. “要票房價值還是要工農兵” (Yao piaofang jiazhi, haishi yao gongnongbing, For the value of box office, or for worker-present-soldier). Zhongguo Dianying 中國電影 2: 15-8.

CHEN, Tina Mai. 2009. "Socialist Geographies, Internationalist Temporalities, and Travelling Film Technologies: Sino-Soviet Film Exchange in the 1950s and 1960s." In Olivia Khoo and Sean Metzger (eds.), Futures of Chinese Cinema: Technologies and Temporalities in Chinese Screen Cultures. Bristol: Intellect. 73-93.

FENG 風. 1955. “蘇聯第一座寬銀幕立體聲電影院揭幕” (Sulian diyizuo kuanyinmu litisheng dianyingyuan jiemu, The inauguration of the first CinemaScope movie theatre in the Soviet Union). Shijie Dianying 世 界電影 9: 95-6.
GUAN, Li 管筥. 1957. “西方寬銀幕發展中的影響和一個悲劇性的 插曲" (Xifang kuanyinmu fazhan zhong de yingxiang he yige beijuxing de chaqu, The influence and a tragic episode in the development of widescreen in the West). Zhongguo Dianying 中國電影 5:63-4.

JIA, Ji 賈䨍. 1957. “電影與觀衆” (Dianying yu guanzhong, Film and audience). Zhongguo Dianying 中國電影 2: 1-6.

LARKIN, Brian. 2013. "The Politics and Poetics of Infrastructure." Annual Review of Anthropology 42: 327-43.

LARKIN, Brian. Signal and Noise: Media, Infrastructure, and Urban Culture in Nigeria. Durham, NC: Duke University Press.

LIN, Shengqing 林聖清, and XUE Zhichang 薛志昌. 1959. “回憶十年 來上影錄音工作的進展” (Huiyi shinian lai shangying luyin gongzuo de jinzhan, The remembrance of the progress of the recording works in Shanghai Film Studio). Dianying Jishu 電影技術 8\&9: 36-7.

LUO, Jingyu 羅靜予 (ed.). 1957. 寬銀幕立體聲譯文選集 (Kuanyinmu litisheng yiwen xuanji, Selected Translation on CinemaScope). Beijing: Zhongguo dianying chubanshe.

LUO, Jingyu 羅靜予. 1957. “從無聲電影到全景電影” (Cong wusheng dianying dao quanjing dianying, From silent film to panoramic film). Zhongguo Dianying 中國電影 11\&12: 20-2.

MA, Shouqing 馬守清. 1959. “蘇聯電影技術的新成就” (Sulian dianying jishu de xinchengjiu, The new achievement of the Soviet's cinematic technology). Dianying Yishu 電影㙯術 5:20-1.

MIAO, Zhenyu 苗振宇. 1957. “永遠難忘的日子” (Yongyuan nanwang de rizi, Days that will never be forgotten). Dazhong Dianying 大衆電影 20: $30-1$.

MITTER, Rana. 2013. "China and the Cold War." In Richard H. Immerman and Petra Goedde (eds.), The Oxford Handbook of the Cold War. Oxford: Oxford University Press. 134-7.

The Propaganda Department of the Party's Committee of Shanghai Film Bureau 上海電影局黨委宣傳部. 1960. “在技術風暴中的上海電影 技術廠” (Zai jishu fengbao zhong de Shanghai dianying jishuchang, The Shanghai Film Technology Factory in the technological storm). Dianying Jishu 電影技術 6: 5-6.

QIAO, Bairen 喬柏人. 2005. 電影院建築工藝與建築聲學設計 
(Dianyingyuan jianzhu gongyi yu jianzhu shengxue sheji, Design of Technology and Acoustics for Cinema). Beijing: Zhongguo jihua chubanshe.

Reporter 記者. 1956. “第一次拍攝寬銀幕影片” (Diyici paishe kuanyinmu yingpian, The production of the first widescreen film). Dazhong Dianying 大衆電影 6: 30-1.

ROGERS, Ariel. 2013. Cinematic Appeals: The Experience of New Movie Technologies. New York: Columbia University Press.

SAUNDERS, Frances Stonor. 2001. The Cultural Cold War: The CIA and the World of Arts and Letters. New York:The New Press.

SHEN, Fu 沈浮. 1957. "在新課題的面前: 赴蘇學習寬銀幕導演處理 的一些體會” (Zai xin keti de mianqian: fusu xuexi kuanyinmu daoyan chuli de yixie tihui, Facing the new project: reflections on the study of the directorial techniques of CinemaScope in the Soviet Union). Zhongguo Dianying 中國電影 6: 91-8.

SITU, Huimin 司徒慧敏. 1955. “蘇聯電影科學與電影技術的輝煌成 就" (Sulian dianying kexue yu dianying jishu de huihuang chengjiu, The brilliant achievement of the cinematic science and technology in the Soviet Union). Dazhong Dianying 大衆電影 7:22-3, 34 .

STERNE, Jonathan. 2003. The Audible Past: Cultural Origins of Sound Reproduction. Durham, NC: Duke University Press.
SU, Yun 蘇雲. 1957. “國際電影節見聞及其他” (Guoji dianyingjie jianwen ji qita, Observations on the international film festival and other things). Dianying Jishu 電影技術 3:17-9.

VIRILIO, Paul. 1989. War and Cinema: The Logistics of Perception. Patrick Camiller (trans.). New York:Verso.

VOLLAND, Nicolai. 2017. Socialist Cosmopolitanism: The Chinese Literary Universe, 1945-1965. New York: Columbia University Press.

VYSOTSKY. 1961. 寬銀幕立體聲電影 (Kuanyinmu litisheng dianying, CinemaScope Films). Wang Ping (trans.). Beijing: Zhongguo dianying chubanshe.

WANG, Xiaojue. 2013. Modernity with a Cold War Face: Reimagining the Nation in Chinese Literature across the 1949 Divide. Cambridge, MA: Harvard University Asia Center.

XU, Qianlin 許淺林. 2005. 中國電影技術發展簡史 (Zhongguo dianying jishu fazhan jianshi, The concise history of the development of Chinese cinematic technology). Beijing: Zhongguo dianying chubanshe.

XUE, Tingfang. 辝廷芳. 1959. “躍進牌'磁性同步錄音機” (“Yuejin pai” cixing tongbu luyinji, The "Leap Forward" magnetic sync recorder). Dianying Jishu 電影技術 1:7-10.

ZHANG, Zhen. 2005. An Amorous History of the Silver Screen: Shanghai Cinema, 1896-1937. Chicago: University of Chicago Press. 